\title{
Comparative Biological Activities of $\alpha$-Rat and $\alpha$-Human Atrial Natriuretic Peptide in the Inhibition of Arginine Vasopressin Release in Conscious Rats
}

\author{
Kenzo KANEKo, Shuichi FUKUDA, San-e ISHIKAWA and \\ ToshikazU SAITO
}

Division of Endocrinology and Metabolism, Jichi Medical School,
Tochigi 329-04, Japan

\begin{abstract}
The comparative biological activities of intracerebroventricular (icv) injection of $\alpha$-rat and $\alpha$-human atrial natriuretic peptide (rANP and hANP, respectively) in the arginine vasopressin (AVP) release in conscious rats and the binding properties of these peptides to their specific receptors have been investigated. An icv injection of $5 \mu \mathrm{g}$ rANP inhibited the AVP release induced by osmotic and hemorrhagic stimuli. In contrast, $20 \mu \mathrm{g}$ of hANP was needed to exert an inhibitory effect on the AVP release. The receptor binding studies were carried out by using rat hypothalamic membrane preparations. The binding studies revealed that the potency of rANP was greater than that of hANP in displacing radioligand from its binding sites. Scatchard analysis revealed that the dissociation constant for rANP was significantly lower than that for hANP $(0.52 \pm 0.04$ vs $1.20 \pm 0.16 \mathrm{nM}, \mathrm{P}<0.01)$. The binding capacity of these peptides was similar. These results suggest that the greater biological potency of rANP compared with hANP in the inhibition of AVP release is caused by the difference in the binding potency of these peptides.
\end{abstract}

It is well established that atrial natriuretic peptide (ANP) elicits natriuresis, diuresis, vasorelaxation, and inhibits aldosterone secretion (Cantin and Genest, 1985). In addition, a number of reports suggest that ANP in the central nervous system may participate in the control of water and electrolyte balance (Nakao et al., 1987). One of the central effects of ANP is its involvement in the control of arginine

Received February 25, 1988

Mail proofs to: KENZO KANEKO, Division of Endocrinology and Metabolism, Jichi Medical School, Minamikawachi-machi, Kawachi-gun, Tochigi-ken 329-04, Japan vasopressin (AVP) release from the neurohypophysis. For example, intravenous injection of ANP has inhibited an AVP release that had been stimulated by dehydration and hemorrhage (Samson, 1985 ; Januszewicz 1986a). An intracerebroventricular (icv) injection of ANP also has attenuated an AVP release induced by dehydration (Iitake et al., 1986), high sodium intake (Poole et al., 1987), and angiotensin II (Takahashi et al., 1986; Yamada et al., 1986 ; Casto et al., 1987). In in vitro studies, ANP has suppressed an AVP release from the isolated posterior pituitary lobes (Obana et al., 1985; Poole et al., 1987) and the 
hypothalamoneurhoypophyseal complex in organ culture (Crandall and Gregg, 1986; Januszewicz et al., 1986b). Thus, these previous reports have demonstrated the inhibitory effects of ANP on AVP release with a few exceptions (Januszewicz et al., 1985 ; Ogawa et al., 1987).

Histoanatomical studies also have indicated the possibility that ANP produced in the central nervous system might regulate the AVP release. Immunoreactive ANP neurons (Kawata et al., 1985 ; Saper et al., 1985 ; Skafitsch et al., 1985) and ANP binding sites (Quirion et al., 1984; Bianchi et al. 1986; Gibson et al., 1986 ; Saavedra et al., Kurihara et al., 1987) have been located in areas responsible for the regulation of AVP release.

Little is known, however, about the differences in the structure-activity relationship in $\alpha$-rat ANP (rANP) and $\alpha$-human ANP (hANP) in the control of the AVP release. It is well recognized that rANP differs from hANP in the replacement of only a single amino acid residue at position 12 of the ANP molecule. The amino acid residues for rANP and hANP are isoleucine and methionine, respectively. In the present study, we have compared the biological activities of the two peptides in the AVP release. Further, we have determined the properties of the ANP binding receptors in the rat hypothalamus.

\section{Materials and Methods}

\section{Indwelling of an icv cannula}

Male Sprague-Dawley rats $(270-320 \mathrm{~g})$ had an indwelling cannula implanted in the lateral ventricle 4 to 6 days prior to all experiments. The surgery was carried out under pentobarbital anesthesia $(40 \mathrm{mg} / \mathrm{kg}$, ip). One stainless steel cannula of $0.6 \mathrm{~mm}$ in outer diameter was stereotaxically inserted into the lateral ventricle, according to the atlas of Paxinos and Watson (1982). Coordinates for the lateral ventricle were $1.5 \mathrm{~mm}$ lateral and $1.0 \mathrm{~mm}$ posterior to the bregma, and $4.6 \mathrm{~mm}$ deep. Rats bearing an icv cannula were kept in individual cages at a constant room temperature and humidity with a 12-h light-dark cycle. Standard chow and water were available ad libitum immediately before the experiments. The position of the cannula was confirmed by injection of methylene blue dye at the end of the experiments.

\section{Osmotic stimulation}

All animals were in a conscious state. Each rat received two successive icv injections. The first icv injection was $5 \mu \mathrm{l}$ of artificial cerebrospinal fluid (ACSF) or the same amount of ACSF containing 5 or $20 \mu \mathrm{g}$ ANP (Peptide Institute Inc., Osaka, Japan). One minute later, either $10 \mu \mathrm{l}$ of ACSF or the same amount of hypertonic ACSF to which $\mathrm{NaCl}$ was added to yield a final concentration of $0.25,0.5$, or $1.0 \mathrm{M}$ was injected. The animals were decapitated one minute after the second icv injection and the trunkal blood was collected into a cold, heparinized beaker. The plasma was separated and stored at $-20^{\circ} \mathrm{C}$ until assayed. The composition of ACSF was as follows (mM) : $\mathrm{NaCl}$ $121, \mathrm{KCl} 3.35, \mathrm{CaCl}_{2} 1.26, \mathrm{MgCl}_{2} 1.16, \mathrm{NaHCO}_{3}$ 21.0, $\mathrm{NaH}_{2} \mathrm{PO}_{4} 0.58$, glucose 3.4 and Urea 2.2,

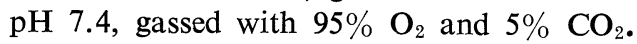

\section{Hemorrhagic stimulation}

Under ether anesthesia, a polyethylene catheter (PE 50, Clay-Adams) was inserted into the femoral artery of rats bearing an icv cannula for monitoring the mean arterial blood pressure (MABP) and for the removal of blood. Experiments were performed with the rats in a conscious state two hours after the withdrawal of ether inhalation. Immediately before the initiation of hemorrhage, $5 \mu \mathrm{l}$ of ACSF, or the same amount of ACSF containing 5 or $20 \mu \mathrm{g}$ ANP, was injected into the lateral ventricle. Hemorrhaging was carried out by removing 1 or $2 \mathrm{ml} / 100 \mathrm{~g}$ body wt of blood over a 3-min period. The animals were decapitated $10 \mathrm{~min}$ after the completion of hemorrhaging and the trunkal blood was collected. The blood was treated in the same manner as described above. MABP was monitored with a strain gage pressure transducer (model PAS-101, Star Medical Co., Tokyo, Japan) throughout the study.

\section{$A V P$ radioimmunoassay}

The plasma AVP concentration was determined 
by radioimmunoassay as described previously (Ishikawa et al. 1986). Briefly, plasma AVP was extracted from acidified plasma using Sep-pak $\mathrm{C}_{18}$ cartridges (Water Associates, Milford, MA). The AVP antiserum was generously supplied by the Mitsubishi Laboratory of Medical Science (Tokyo, Japan). ${ }^{125}$ I-AVP was purchased from New England Nuclear (Boston, MA). Synthetic AVP (grade VI, Sigma, St. Louis, MI) was used for the standard curves. The minimal detection limit of the assay was $0.125 \mathrm{pg} /$ tube. Inter- and intraassay coefficients of variation were less than $10 \%$.

\section{ANP binding assay}

Preparation for an ANP binding assay in the rat hypothalamic membrane was carried out according to the method of Quirion et al. (1986) with minor modifications. Briefly, SpragueDawley rats (240-280 g) were decapitated and seven regions were separated on ice as previously described (Glowinski and Iversen, 1966). Hypothalamic tissues were homogenized in 10 volumes of $150 \mathrm{mM}$ Tris- $\mathrm{HCl}$ buffer $\left(\mathrm{pH} 7.4\right.$ at $\left.4^{\circ} \mathrm{C}\right)$ containing $120 \mathrm{mM} \mathrm{NaCl}$ and $5 \mathrm{mM} \mathrm{KCl}$ using a teflon homogenizer. The homogenates were centrifuged for $10 \mathrm{~min}$ at $42,000 \times \mathrm{g}$. The pellets were resuspended in 10 volumes of $50 \mathrm{mM}$ Tris$\mathrm{HCl}$ buffer ( $\mathrm{pH} 7.4$ at $4^{\circ} \mathrm{C}$ ) containing $300 \mathrm{mM}$ $\mathrm{KCl}$ and $10 \mathrm{mM} \mathrm{Na}_{2}$ EDTA, and incubated on ice for $30 \mathrm{~min}$. After the centrifugation described above, the pellets were resuspended in 20 volumes of $50 \mathrm{mM}$ Tris- $\mathrm{HCl}$ buffer $\left(\mathrm{pH} 7.4\right.$ at $4^{\circ} \mathrm{C}$ ) and recentrifuged at $42,000 \times \mathrm{g}$ for $15 \mathrm{~min}$. The final pellets were washed twice with $50 \mathrm{mM}$ Tris- $\mathrm{HCl}$ buffer $\left(\mathrm{pH} 7.4\right.$ at $4^{\circ} \mathrm{C}$ ) and resuspended in 60 volumes of the same buffer.

For binding assyas, $200 \mu \mathrm{l}$ of membrane suspension were incubated for $60 \mathrm{~min}$ at $25^{\circ} \mathrm{C}$ with $400 \mu \mathrm{l}$ of assay buffer containing various concentrations of unlabeled ANP and $10 \mathrm{pM}$ of ${ }^{125}$ I-ANP (Amersham International plc, Buckinghamshire, England). The assay buffer was $50 \mathrm{mM}$ Tris-HCl buffer ( $\mathrm{pH}$ 7.4) containing $150 \mathrm{mM}$ $\mathrm{NaCl}, 5 \mathrm{mM} \mathrm{MnCl}, 40 \mu \mathrm{g} / \mathrm{ml}$ bacitracin (Sigma) and $0.5 \%$ bovine serum albumin (fraction V, Sigma) After 60-minute incubation, each assay tube was filled rapidly with $5 \mathrm{ml}$ of the ice-cold assay buffer. Diluted solutions were filtered through whatman GF/C filters (Maidstone, England) presoaked for one hour in $0.1 \%$ polyethyleneimine. Each filter was washed three times with $5 \mathrm{ml}$ of the cold assay buffer. Specific binding was calculated as the difference in radioactivity bound in the presence and absence of $2 \times 10^{-6} \mathrm{M}$ unlabeled ANP. Binding of ligands to filters was quantitated by counting the filters in a $\gamma$-counter (model ARC-600, Aloka, Tokyo, Japan). All assays were done in triplicate. Protein was determined by the method of Lowry et al. (1951).

\section{Statistics}

Statistical analysis was performed by analysis

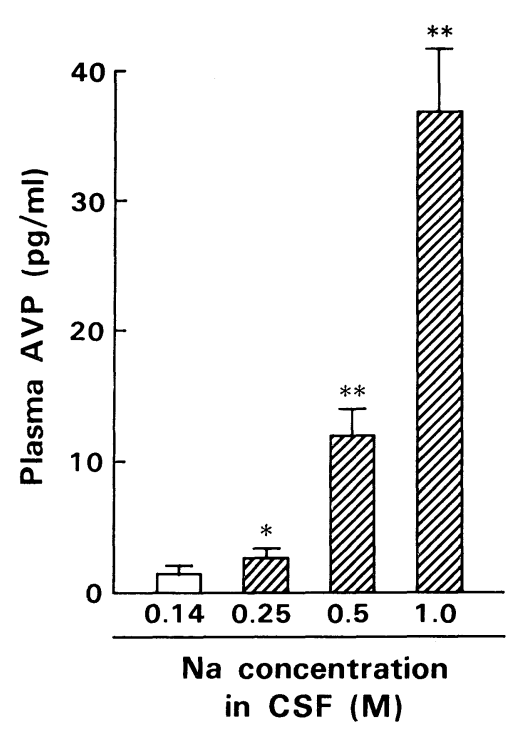

Fig. 1. Plasma arginine vasopressin (AVP) levels after intracerebroventricular injection of hypertonic artificial cerebrospinal fluid (CSF) or hemorrhage. The number of animals in each group is seven. Values are the mean \pm SEM. * and ** represent $\quad \mathbf{P}<0.05$ and $\mathbf{P}<0.01$, respectively, compared with $0.14 \mathrm{M}$ sodium-containg CSF injected rats (left panel) and sham operated rats (right panel). 
of variance with the multiple comparisons (Dunn and Clark, 1974), and by paired or unpaired $t$ test, where appropriate. A P value less than 0.05 was considered significant. Values have been represented as the mean $\pm \mathrm{SEM}$.

\section{Results}

\section{Effects of ANP on the AVP releasse}

As shown in the left panel of Fig. 1, the plasma AVP concentration increased in a dose-dependent manner in response to icv injections of hypertonic ACSF. Fig. 2 shows

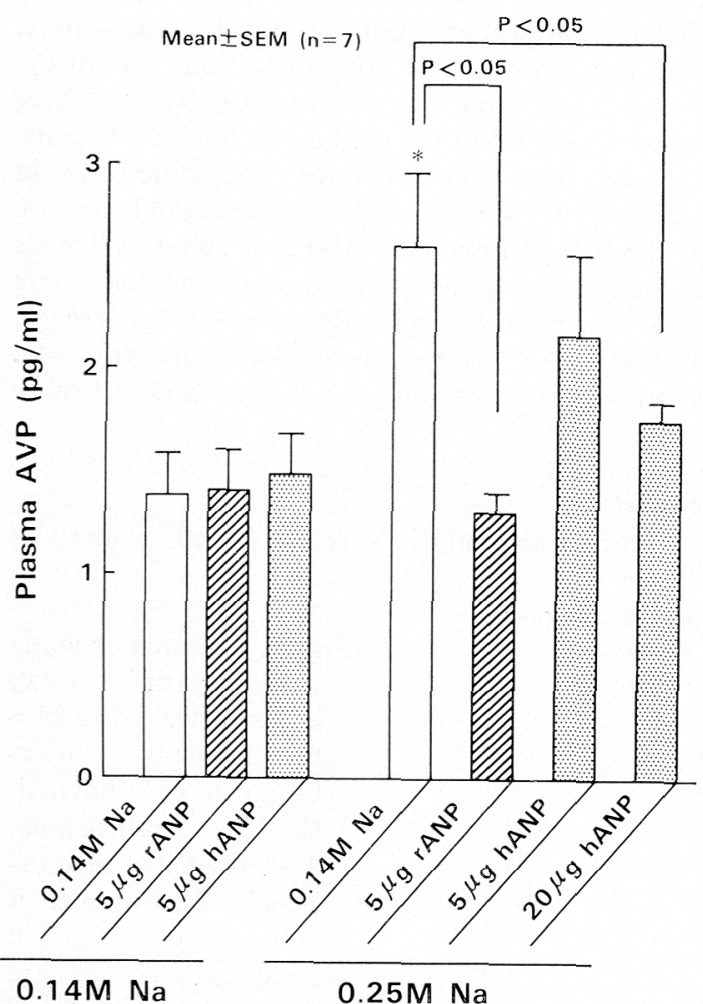

Fig. 2. Effects of intracerebroventricular (ICV) injection of atrial natriuretic peptide (ANP) on arginine vasopressin (AVP) release induced by icv injection of hypertonic artificial cerebrospinal fluid (CSF) containing $0.25 \mathrm{M}$ sodium. The number of animals in each group is seven. $* \mathbf{P}<0.05$ vs $0.14 \mathrm{M}$ sodium-containing CSF injected rats. rANP and hANP represent $\alpha$-rat and $\alpha$-human ANP, respectively. the effects of icv injection of ANP on plasma AVP. The increase in plasma AVP in response to hypertonic ACSF containing $0.25 \mathrm{M}$ sodium was significantly attenuated by icv injection of $5 \mu \mathrm{g}$ rANP. In contrast, an icv injection of $5 \mu \mathrm{g}$ hANP did not suppress AVP release stimulated by $0.25 \mathrm{M}$

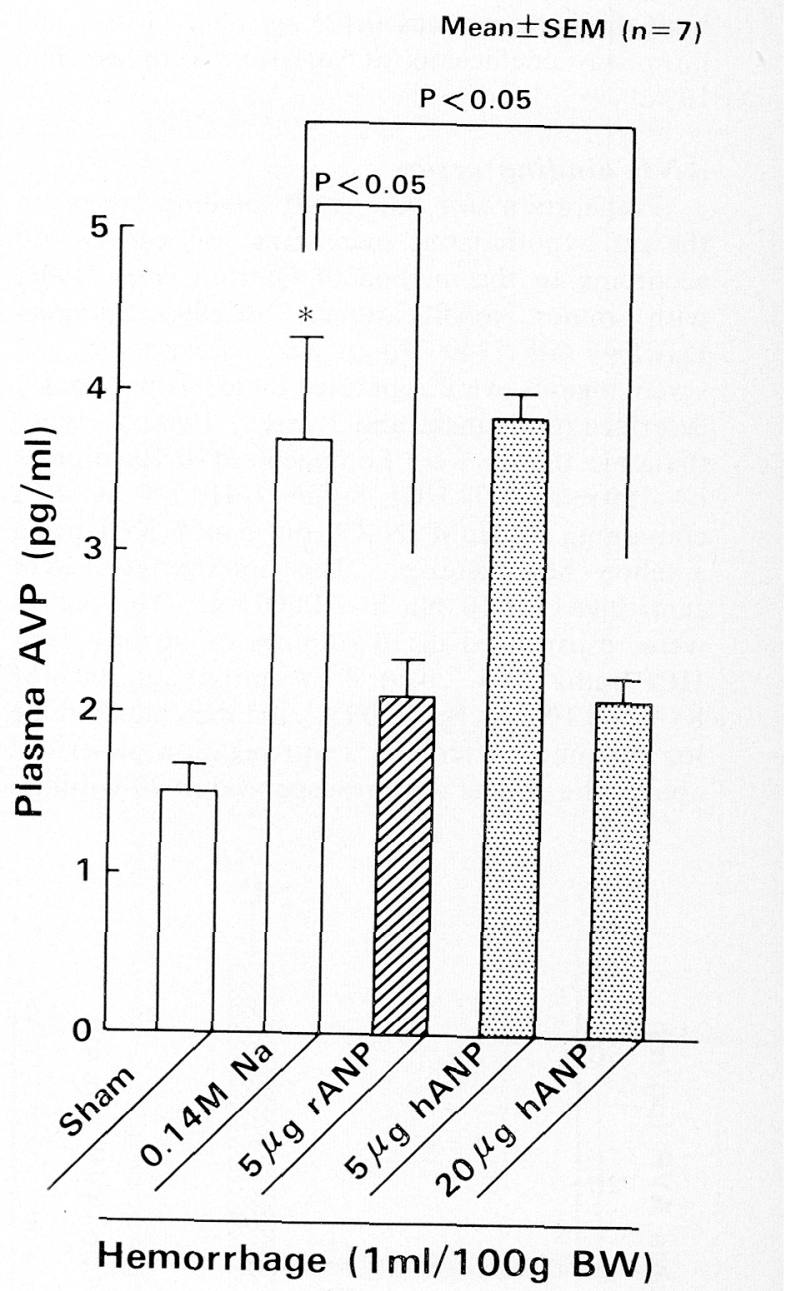

Fig. 3. Effects of intracerebroventricular injection of atrial natriuretic peptide (ANP) on arginine vasopressin (AVP) release induced by hemorrhage $(1.0 \mathrm{ml} / 100 \mathrm{~g}$ body wt). The number of animals in each group is seven. Values are the mean \pm SEM. $* \mathbf{P}<0.05$ vs sham operated rats. rANP and hANP represent $\alpha$ rat ANP and $\alpha$-human ANP, respectively. 
Table 1. Mean arterial blood pressure before and after hemorrhage.

\begin{tabular}{|c|c|c|c|c|}
\hline \multicolumn{2}{|l|}{ Treatment } & \multirow{2}{*}{$\mathrm{n}$} & \multicolumn{2}{|c|}{ Blood pressure $(\mathrm{mmHg})$} \\
\hline Hemorrhage & ICV & & Before & After \\
\hline Sham & ACSF & 7 & $106 \pm 1.9$ & $106 \pm 2.0$ \\
\hline \multirow[t]{4}{*}{$1 \mathrm{ml} / 100 \mathrm{~g} \mathrm{BW}$} & ACSF & 7 & $106 \pm 1.8$ & $100 \pm 1.5^{*}$ \\
\hline & $5 \mu \mathrm{g}$ rANP & 7 & $107 \pm 2.1$ & $102 \pm 2.6^{*}$ \\
\hline & $5 \mu \mathrm{g}$ hANP & 7 & $105 \pm 2.0$ & $100 \pm 1.9 *$ \\
\hline & $20 \mu \mathrm{g} \mathrm{hANP}$ & 7 & $106 \pm 2.0$ & $100 \pm 2.1 *$ \\
\hline $2 \mathrm{ml} / 100 \mathrm{~g} \mathrm{BW}$ & ACSF & 6 & $105 \pm 1.8$ & $76 \pm 7.6^{* *}$ \\
\hline
\end{tabular}

$* \mathbf{P}<0.01, * * \mathbf{P}<0.001$ vs before hemorrhage. Values are the mean \pm SEM. ACSF, artificial cerebrospinal fluid; ICV, intracerebroventricular injection; $n$, the number of animals; $B W$, body weight.

sodium containing hypertonic ACSF. An icv injection of $20 \mu \mathrm{g}$ hANP, meanwhile, inhibited the AVP release significantly. Neither rANP nor hANP had any effect on the basal AVP release.

As shown in the right panel of Fig. 1, in response to hemmorhage, plasma AVP increased in a dose-dependent manner. Fig. 3 shows the effects of ANP on the AVP release induced by hemmorrhage (1.0 $\mathrm{ml} / 100 \mathrm{~g}$ body $\mathrm{wt})$. As observed in the osmotic stimuli, an increase in plasma AVP after hemorrhage was attenuated by an icv injection of $5 \mu \mathrm{g}$ of rANP. Although the icv injection of $5 \mu \mathrm{g}$ of hANP did not inhibit the AVP release induced by hemorrhage, $20 \mu \mathrm{g}$ of hANP inhibited the AVP release. The changes in MABP were similar in the groups with $1 \mathrm{ml} / 100 \mathrm{~g}$ body wt of hemorrhage (Table 1).

\section{ANP binding study}

Since specific binding of ${ }^{125} \mathrm{I}-\mathrm{rANP}$ increased lineary up to $280 \mu \mathrm{g}$ protein $/ \mathrm{ml}$ (Fig. 4, upper panel), this membrane concentration was used in the following binding studies. The relationship between the time of incubation and the specific binding of ${ }^{125}$ I-rANP is shown in the lower panel of Fig. 4. The specific binding reached its maximal within $30 \mathrm{~min}$ and then maintained this plateau for at least $30 \mathrm{~min}$. We used a 60-min incubation time in all experiments described hereafter.

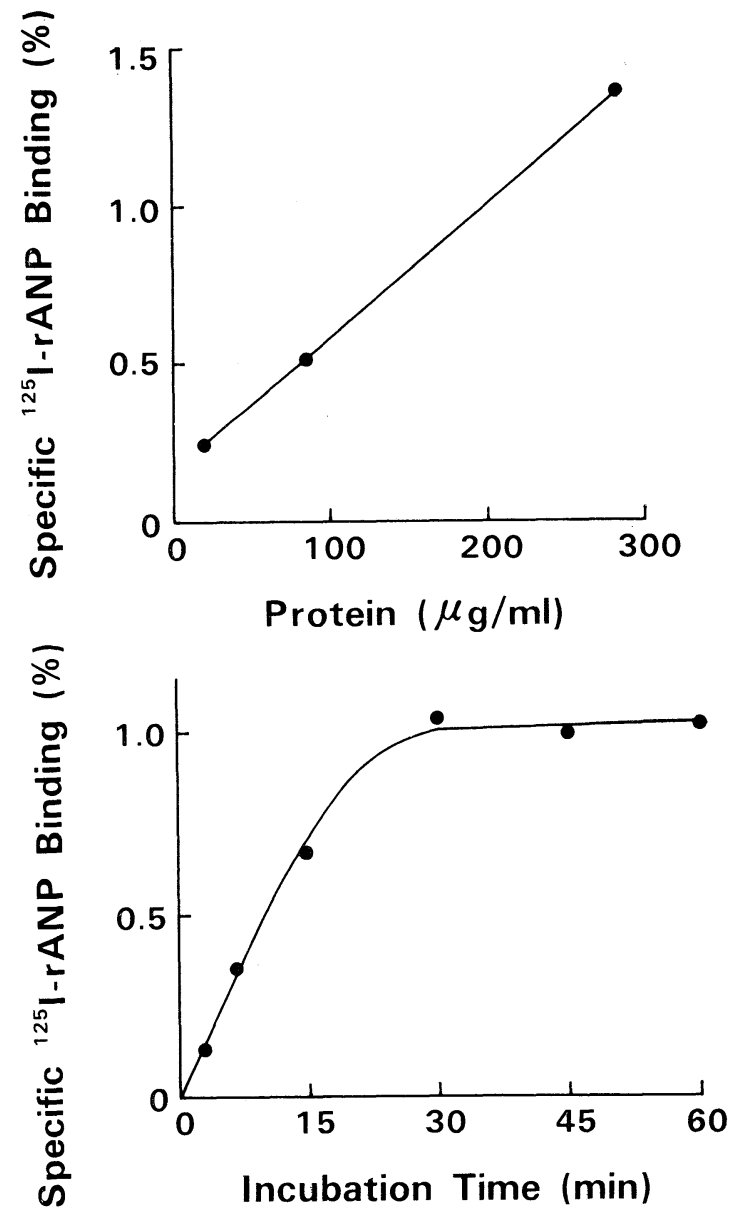

Fig. 4. Upper panel; Specific ${ }^{125}$ I-rat atrial natriuretic peptide (rANP) binding as a proteindependent reaction in rat hypothalamic membrane preparations.

Lower panel; Time course of specific ${ }^{125} \mathrm{I}-$ rANP binding in rat hypothalamic membrane preparations. 
Table 2. Comparative receptor binding properties of rANP and hANP in the rat hypothalamic membrane preparations.

\begin{tabular}{lcccc}
\hline \hline & $\mathrm{n}$ & $\begin{array}{c}\mathrm{IC}_{50} \\
(\mathrm{nM})\end{array}$ & $\begin{array}{c}\mathrm{K}_{\mathrm{d}} \\
(\mathrm{nM})\end{array}$ & $\begin{array}{c}\mathrm{B}_{\max } \\
(\mathrm{fM} / \mathrm{mg} \text { protein })\end{array}$ \\
\hline$\alpha$-rat ANP & 6 & $0.34 \pm 0.17$ & $0.52 \pm 0.04$ & $40.3 \pm 2.5$ \\
$\alpha$-human ANP & 5 & $1.14 \pm 0.35^{*}$ & $1.20 \pm 0.16^{* *}$ & $39.1 \pm 6.4$ \\
\hline
\end{tabular}

Values are the mean \pm SEM. $\mathrm{n}$, the number of binding studies; $\mathrm{IC}_{50}$, the concentration of unlabeled ANP required to displace $50 \%$ of ${ }^{125} I$-ANP binding; $K_{d}$, "dissociation constant; $\mathbf{B}_{\text {max }}$, maximal binding capacity. $* \mathbf{P}<0.02$. ${ }^{* *} \mathbf{P}<0.01$ vs $\alpha$-rat ANP.
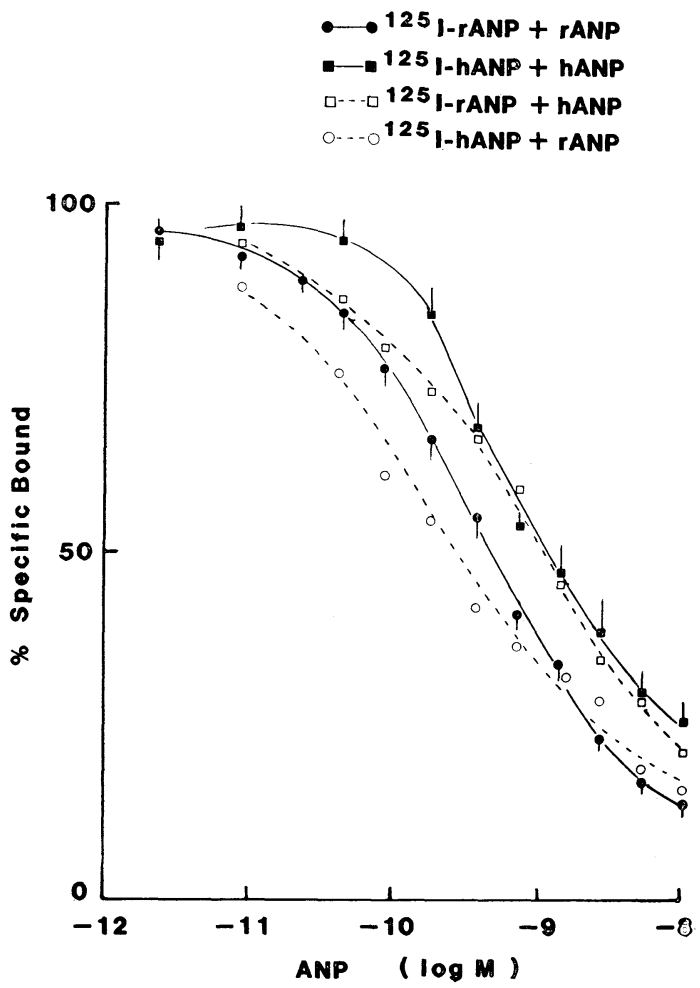

Fig. 5. Displacement curves of specific ${ }^{125} \mathrm{I}$ atrial natriuretic peptide (ANP) binding in response to various concentrations of unlabeled ANP in rat hypothalamic membrane preparations. ( $-\bigcirc)$, ( $\square-\square),(\square-\cdots \square)$, and $(\bigcirc-\cdots)$ represent ${ }^{125}$ I-rANP binding displaced by unlabeled rANP, ${ }^{125}$ I-hANP binding displaced by unlabeled hANP, ${ }^{125}$ I-rANP binding displaced by unlabeled hANP, and ${ }^{125}$ I-hANP binding displaced by unlabeled rANP, respectively.

Displacement-curves of ${ }^{125}$ I-ANP binding to the hypothalamic membrane receptor in the presence of unlabeled ANP are shown in Fig. 5. The concentration of unlabeled rANP required to displace $50 \%$ of ${ }^{125} \mathrm{I}-$ rANP binding $\left(\mathrm{IC}_{50}\right)$ was significantly $(\mathrm{P}<0.02)$ lower than that of unlabeled hANP $\quad(0.34 \pm 0.17$ vs $1.14 \pm 0.35 \mathrm{nM}$, Table 2). Similarly, the $\mathrm{IC}_{50}$ of unlabeled rANP to displace ${ }^{125}$ I-hANP binding was lower than that of unlabeled hANP $(0.16$ $\mathrm{nM}$ and $1.05 \mathrm{nM}$, respectively.) Scatchard analysis performed by Rosenthal's method (1967) revealed that the hypothalamic ANP receptors consisted of those with a high and a low affinity (Fig. 6). The dissociation constant $\left(\mathrm{K}_{\mathrm{d}}\right)$ of the high affinity receptor for rANP was significantly $(\mathrm{P}<0.01)$ lower than that for hANP $(0.52 \pm 0.04$ vs $1.20 \pm$ $0.16 \mathrm{nM}$, Table 2). The maximal binding capacity $\left(B_{\max }\right)$ of the high affinity receptors for rANP was not significantly different from that for hANP (Table 2). Since there were considerable variations in the experimental data for the low affinity receptors, it was difficult to analyse its binding parameters. It was also difficult to calculate the average affinity proposed by De Meyts $e t$ al. (1975), since the abcissa intercept could not be decided.

\section{Discussion}

The present results show that centrally admistered ANP inhibited the AVP release induced by osmotic and hemorrhagic stimuli. The dose of hANP necessary for this inhibition of the AVP release was greater 


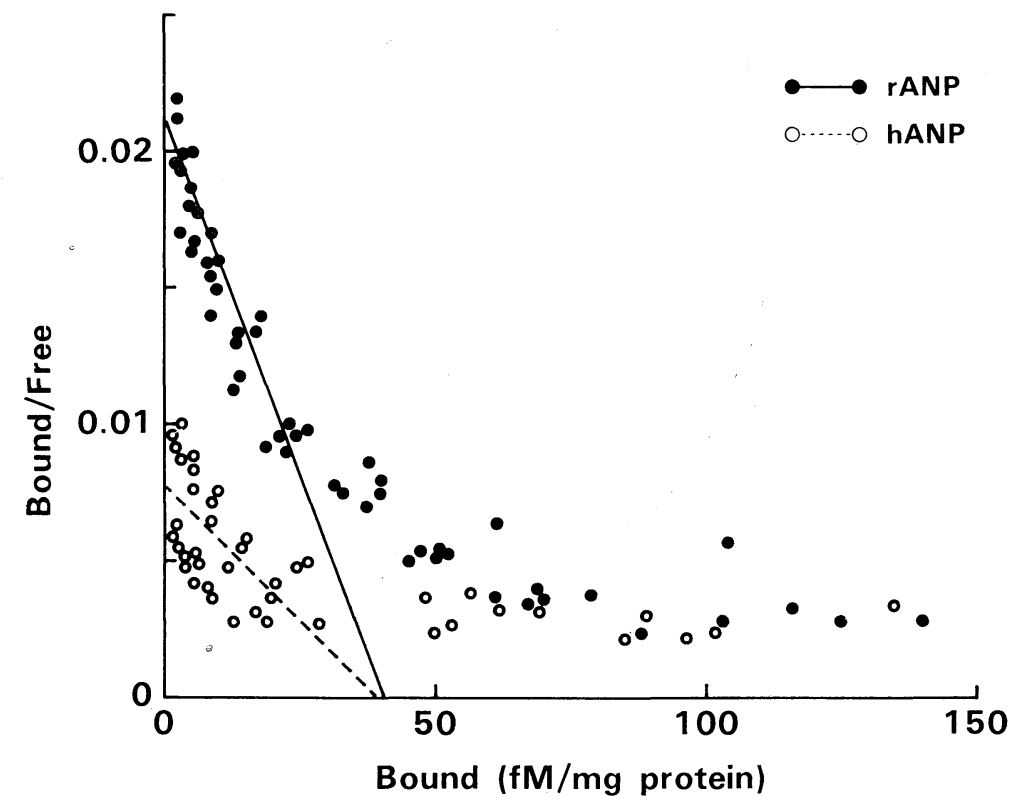

Fig. 6. Scatchard analysis of atrial natriuretic peptide (ANP) binding to rat hypothalamic membrane preparations. Data were obtained by ${ }^{125}$ I-rANP binding displaced by unlabeled rANP (-), and by ${ }^{125}$ I-hANP binding displaced by unlabeled and hANP $(\bigcirc \cdots \bigcirc)$. rANP and hANP represent $\alpha$-rat ANP and $\alpha$-human ANP, respectively.

than that of rANP and the receptor binding potency of rANP was stronger than that of hANP.

The inhibitory effects of ANP on AVP release found in our study are consistent with a number of previous reports. Ogawa et al. (1987) reported that neither an icv injection of rANP $(0.3 \mathrm{nM} / \mathrm{kg})$ nor an intravenous injection $(2.5 \mathrm{nM} / \mathrm{kg})$ has produced any effects on the plasma AVP concentration in the dehydrated rat. They have therefore concluded that the physiological levels of ANP did not affect the AVP release in vivo. The dose of ANP administered by Ogawa et al. was much smaller than that in our study, so that our dose of ANP might be considered pharmacological. Thus, further investigations are needed to clarify the physiological significance of ANP in the the reugulation of AVP release.

The present results have revealed that the biological activity of rANP appear to be more potent than that of hANP in the inhibition of the AVP release. This comparative biological potency of the two peptides was confirmed by the receptor binding properties found in the present study. There have been no reports indicating that the biological potencies of the two peptides differ from each other in the central nervous system. Itoh et al. (1987) have reported that centrally administered hANP exerts an equipotent antidipsogenic action compared with rANP in the conscious rat. The reason for the difference between the two remains unclear.

The present receptor binding studies have demonstrated that the affinity constant for rANP was greater than that for hANP, especially in the high affinity binding sites. Quirion et al. (1986) have reported that the binding properties of rANP were almost equal to those of hANP in the hypothalamic membrane receptors of the guinea pig. This contradiction may be due to the difference in the species of animal used in the two experiments. On the one hand, the possibility that the oxydation of methionine at position 12 of hANP molecule decreased the binding and the biological activity of hANP cannot be excluded. However, we did not observe a progressive fall in the binding or the biological activity of hANP during the present study. 
The presence of specific ANP binding sites in the hypothalamus as observed in our study suggests that the inhibitory effect of ANP on AVP release might be exerted in the hypothalamus. Standaert et al. (1987) reported that the firing of the vasopressin neurons in the posterior magnocellular paraventricular subnucleus has been inhibited by the injection of ANP into this area. Wong et al. (1986) have also reported that the firing rate of the rat medial preoptic area is decreased by the injection of ANP into this area. Samson et al. (1987) have concluded that ANP inhibited the AVP release via the hypothalamus, since ANP inhibited the AVP release from the hypothalamo-neurohypophyseal complex without any effects in the isolated neurohypophysis. However, the possibility that other areas abundant in ANP binding sites, such as the subfornical organ and the area postrema, are responsible for the inhibitory effect of ANP on the AVP release cannot be excluded.

In conclusion, the greater biological potency of rANP compared with hANP in the inhibition of the AVP release is caused by the difference in the receptor binding potency of the two peptides.

\section{Acknowledgements}

This work was supported by a Grant-in-aid for special Project Research on Plasticity of Neural Circuits from the Japanese Ministry of Education, Science and Culture.

\section{References}

Bianchi, C., J. Gutowska, M. Ballak, G. Thibault, J. Garcia, J. Genest and M. Cantin (1986). Radioautographic localization of ${ }^{125}$ I-atrial natriuretic factor binding sites in the brain. Neuroendocrinology 44, 365-372.

Cantin, M. and J. Genest (1985). The heart and the atrial natriuretic factor. Endocrine Rev. 6,
107-127.

Casto, R., I. Keiler, G. Schroeder and G. Stock (1987). Angiotensin II-induced vasopressin is attenuated by central atrial natriuretic factor. Clin. and Exper. Theory and Practice. A9, 81-94.

Crandall, M. E. and C. M. Gregg (1986). In vitro evidence for an inhibitory effect of atrial natriuretic peptide on vasopressin release. Neuroendocrinology 44, 439-445.

De Meyts, P. and D. Roth (1975). Cooperativity in ligand binding: a new graphic analysis. Biochem. Biophys. Res. Commun. 66, 11181126.

Dunn, O. J. and Clark, V. A. (1974). One-way analysis of variance. In : Applied Statistics : Analysis of Variance and Regression, John Wiley \& Sons, Inc., New York. pp. 62-85.

Gibson, T. R., G. M. Wildey, S. Manaker and C. C. Glembotski. (1986). Autoradiographic localization and characterization of atrial natriuretic peoptide binding sites in the rat central nervous system and adrenal gland. J. Neuroci. 6, 2004-2011.

Glowinski, J. and L. L. Iversen (1966). Regional studies of catecholamines in the rat brain $I$. The dissociation of $\left[{ }^{3} \mathrm{H}\right]$ dopamine and $\left[{ }^{3} \mathrm{H}\right]$ dopa in various regions of the brain. $J$. Neurochem. 13, 655-669.

Iitake, K., L. Share, J. T. Crofton, D. P. Brooks, Y. Ouchi and E. H. Blaine (1986). Central atrial natriuretic factor reduces vasopressin secretion in the rat. Endocrinology 119, 438450.

Ishikawa, S., T. Saito, K. Okada, K. Tsutsui and T. Kuzuya (1986). Effect of vasopressin antagonist on water excretion in inferior vena cava constriction. Kidney Int. 30, 49-55.

Itoh, H., K. Nakao, G. Katsuura, N. Morii, S. Shiono, T. Yamada, A. Sugawara, Y. Saito, $\mathrm{K}$. Watanabe, $\mathrm{K}$. Igano, $\mathrm{K}$. Inoue and $\mathrm{H}$. Imura (1987). Atrial natriuretic polypeptides : structure-activity relationship in the central action - a comparison of their antidipsogenic action Neurosci. Lett. 74, 102-106.

Januszewicz, P., J. Gutkowska, A. De Lean, G. Thibault, R. Garcia, J. Genest and M. Cantin (1985). Synthetic atrial natriuretic factor induces release (possibly receptor-mediated) of vassopressin from rat posterior pituitary. Proc. Soc. Exp. Biol. Med. 178, 321-325.

Januszewicz, P., P. Larose, H. Ong, J. Gutkowska and J. Genest (1986a). Effect of atrial natriuretic 
factor on plasma vasopressin in conscious rats. Peptides 7, 989-993.

Januszewicz, P., G. Thibault, R. Garcia, J. Gutkowska, J. Genest and M. Cantin (1986b). Effect of synthetic atrial natriuretic factor on arginine vasopressin release by the rat hypothalamo-neurohypophysial complex in organ culture. Biochem. Biophys. Res. Commun. 134, 652-658.

Kawata, M., K. Nakao, N. Morii, Y. Kiso, H. Yamashita, H. Imura and Y. Sano (1985). Atrial natriuretic polypeptide; Topographical distribution in the rat brain by radioimmunoassay and immunohistochemistry. Neuroscience 16, 521-546.

Kurihara, M., J. M. Saavedra and K. Shigematsu (1987). Localization and characterization of atrial natriuretic peptide binding sites in discrete areas of rat brain and pituitary gland by quantitative autoradiography. Brain Res. 408, 31-39.

Lowry, O. H., N. J. Rosebrough, A. L. Farr and R. J. Randall (1951). Protein measurement with the folin phenol reagent. J. Biol. Chem. 193, 265-275.

Nakao, K., N. Morii, H. Itoh, T. Yamada, S. Shiono, A. Sugawara, Y. Saito, M. Mukoyama, H. Arai, M. Sakamoto and H. Imura (1987). Atrial natriuretic polypeptide in brain -Implication of central cardiovascular control. Klin. Wochenschr. 65, (Suppl VIII), 103-108.

Obana, K., M. Naruse, T. Inagami, A. B. Brown and K. Naruse, F. Kurimoto, H. Sakurai, H. Demura and K. Shizume (1985). Atrial natriuretic factor inhibits vasopressin secretion from rat posterior pituitary. Biochem. Biophys. Res. Commun. 132, 1088-1094.

Ogawa, K., L. F. Arnolda, E. A. Woodcock, M. Hiwatari and C. I. Johnston (1987). Lack of effect of atrial natriuretic peptide of vasopressin release. Clin. Sci. 72, 525-530.

Paxinos, G. and C. Watson (1982). The Rat Brain in Stereotaxic Coordinates. Academic Press, Australia.

Poole, C. J. M., D. A. Carter, M. Vallejo and S. L. Lightman (1987). Atrial natriuretic factor inhibits the stimulated in vivo and in vitro release of vasopressin and oxytocin in the rat. J. Endocrinol. 112, 97-102.

Quirion, R., M. Dalpe, A. De Lean, J. Gutkowska, M. Cantin and J. Genest (1984). Atrial natriuretic factor (ANF) binding sites in brain and related structures. Peptides 5,
1167-1172.

Quirion, R., M. Dalpe and D. Than-Vink (1986). Characterization and distribution of receptors for the atrial natriuretic peptides in mammalin brain. Proc. Natl. Acad. Sci. USA. 83, 174-178.

Rosenthal, H. E. (1967). A graphic method for the determination and presentation of binding parameters in a complex system. Anal. Biochem. 20, 525-532.

Saavedra, J. M., F. M. A. Correa, L. M. Plunkett, A. Israel, M. Kurihara and K. Shigematsu (1986). Binding of angiotensin and atrial natriuretic peptide in brain of hypertensive rats. Nature 320, 758-760.

Semson, W. K. (1985). Atrial natriuretic factor inhibits dehydration and hemorrhage-induced vesopressin release. Neuroendocrinology 40, 277-279.

Samson, W. K., M. C. Aguila, J. Martinovic, J. Antunes-Rodrigues and M. Norris (1987). Hypothalamic action of atrial natriuretic factor to inhibit vasopressin secretion. Peptides 8, 449-454.

Saper, C. B., D. G. Standaert, M. G. Currie, D. Schwartz, D. M. Geller and P. Needleman (1985). Atriopeptin-immunoreactive neurons in the brain: Presence in cardiovascular regulatory areas. Science 227, 1047-1049.

Scofitsch, G., M. Jacobwitz, R. L. Eskay and N. Zamir (1985). Distribution of atrial natriuretic factor-like immunoreactive neurons in the rat brain. Neuroscience 16, 917-948.

Standaert, D. G., D. F. Cechetto, P. Needleman and C. B. Saper (1987). Inhibition of the firing of vasopressin neurons by atriopeptin. Nature 329, 151-153.

Takahashi, H., H. Okabayashi, H. Suga, M. Matsuzawa, I. Ikegaki, M. Yoshimura and H. Ijichi (1986). Inhibitory roles of the hypothalamic atrial natriuretic polypeptide on the vasopressin release in sodium-loaded rats. Biochem. Biophys. Res. Commun. 139, 1285-1291.

Wong, M., W. K. Samson, C. A. Dudley and R. L. Moss (1986). Direct, neuronal action of atrial natriuretic factor in the rat brain. Neuroendocrinology 44, 49-53.

Yamada, T., K. Nakao, N. Morii, H. Itoh, S. Shiono, M. Sakamoto, A. Sugawara, Y. Saito H. Ohno, A. Kanai, G. Katsuura, M. Eigyo, A. Matsushita and H. Imura (1986). Central effect of artrial natriuretic polypeptide on angiotensin II-stimulated vasopressin secretion in conscious rats. Eur. J. Pharmacol. 125, 453-456. 